\title{
Influence of constant and periodic experimental hypoxic stress on Atlantic croaker otolith chemistry
}

\author{
John Mohan*, Md. Saydur Rahman, Peter Thomas, Benjamin Walther
}

University of Texas at Austin, Marine Science Institute, Port Aransas, Texas 78373, USA

\begin{abstract}
The chemical composition of fish otoliths may provide information on the environmental exposure histories of fishes if 'vital effects' on element incorporation are minimal. In order to use redox-sensitive geochemical proxies, such as manganese, in otoliths to quantify sublethal exposure to hypoxia, the relative influence of endogenous and exogenous controls on otolith composition must first be validated. Controlled laboratory experiments were conducted on Atlantic croaker Micropogonias undulatus to examine the response of otolith $\mathrm{Sr}: \mathrm{Ca}, \mathrm{Ba}: \mathrm{Ca}$, $\mathrm{Mg}: \mathrm{Ca}, \mathrm{Mn}: \mathrm{Ca}$, and $\mathrm{Na}$ :Ca ratios to either constant or periodic hypoxia treatments for 4 and $10 \mathrm{wk}$, respectively. Although fish somatic growth and condition were affected by constant hypoxia, no difference in otolith chemistry relative to normoxic control treatments was detected. Similar to the 4 wk study, there was no difference in otolith chemistry between fish (males and females combined) exposed $10 \mathrm{wk}$ to constant hypoxia and control normoxic fish. Periodic hypoxia significantly decreased otolith $\mathrm{Ba}: \mathrm{Ca}$ and $\mathrm{Mg}: \mathrm{Ca}$ in both males and females and reduced $\mathrm{Sr}: \mathrm{Ca}$ in males, and there was a slight effect of sex on otolith Mn:Ca. Significant interactions between treatment and sex were detected for otolith $\mathrm{Sr}: \mathrm{Ca}$ and $\mathrm{Na}: \mathrm{Ca}$, possibly related to combined stresses of gonadal development and periodic hypoxic stress. Although responses to treatments were observed for some elements, the magnitudes of responses were minimal compared to exogenous variation driven by water chemistry composition reported in previous laboratory and field investigations. The otolith chemistry of Atlantic croaker is therefore minimally influenced by endogenous factors in response to hypoxic stress, which has important implications for interpreting otolith chemical chronologies of wild fish collected within natural hypoxic regions.
\end{abstract}

KEY WORDS: Hypoxia - Otolith chemistry $\cdot$ Micropogonias undulatus - Manganese - Trace elements · Physiological stress

*Corresponding author: john.mohan@utexas.edu

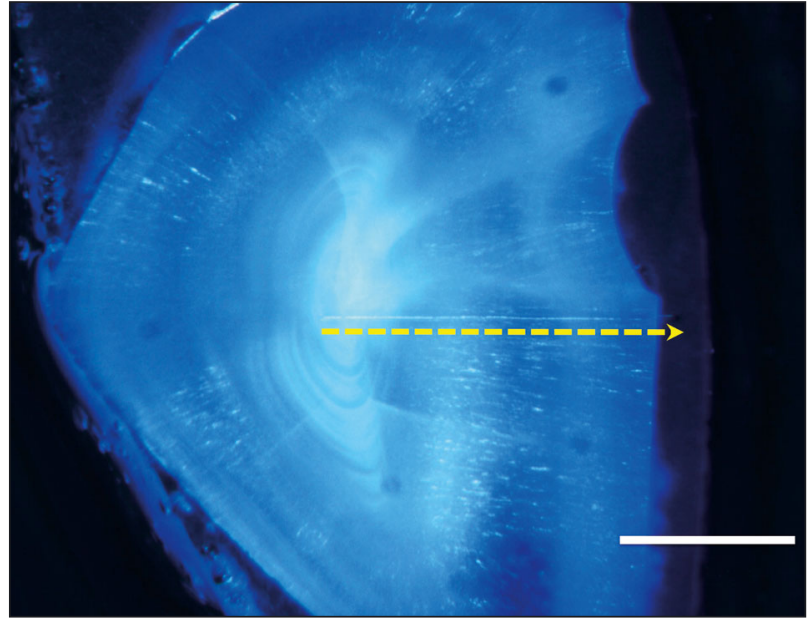

Sectioned otolith of Atlantic croaker Micropogonias undulatus, showing laser transect (faint line above the yellow dashed line) from core (early life) to edge (experimental period). Scale bar $=850 \mu \mathrm{m}$

Photo: J. Mohan

\section{INTRODUCTION}

Hypoxia (dissolved oxygen $<2 \mathrm{mg} \mathrm{O} \mathrm{O}_{2} \mathrm{l}^{-1}$ ) is increasing in frequency and severity in coastal ecosystems worldwide due to human activities (Diaz \& Rosenberg 2008). Fish exposed to hypoxia have exhibited negative sublethal physiological effects including reduced growth (McNatt \& Rice 2004), shifts in habitat (Craig 2012), and reproductive disorder (Thomas \& Rahman 2012), yet less is known about natural exposure levels that elicit damaging organismal and ecological responses, especially for mobile species capable of sensing, tolerating, and avoiding hypoxia (Froeschke \& Stunz 2011). A validated chronological geochemical proxy indicating hypoxia exposure in fishes is needed to assess the long-term sublethal effects of hypoxic exposure on aquatic communities.

(C) The authors 2014. Open Access under Creative Commons by Attribution Licence. Use, distribution and reproduction are unrestricted. Authors and original publication must be credited. 
Fish respond to an oxygen challenge by first attempting to extract more oxygen from the water using strategies of increasing gill ventilation rates, red blood cell counts, and hemoglobin $\mathrm{O}_{2}$-binding capacity (Wu 2002). If the oxygen challenge persists, they will depress metabolism and 'turn down the pilot light' (Hochachka et al. 1996) and initiate energy conserving pathways by downregulating protein synthesis and modifying enzymes to decrease ATP use (Wu 2002, Bickler \& Buck 2007). Many hypoxia-responsive pathways are turned on via the 'master switch', the hypoxia-inducible factor HIF- $\alpha$, a heterodimeric transcription factor (Nikinmaa \& Rees 2005, Rahman \& Thomas 2007). HIF- $\alpha$ is expressed in a wide range of fish tissues and codes for genes related to red blood cell production, vascularization, apoptosis, and carbohydrate metabolism. Under normoxic conditions, the HIF protein is degraded, but the protein accumulates under hypoxic exposure. Short-term biomarkers, such as HIF$\alpha$, provide reliable molecular indicators of exposure to hypoxia in several fish (Thomas \& Rahman 2009) and crustacean (Kodama et al. 2012) species on time scales of hours to days. However, HIF- $\alpha$ mRNA expression returns to basal levels within $24 \mathrm{~h}$ after recovery from hypoxia, offering no information on lifetime patterns of exposure and the potential for long-term sublethal effects (Rahman \& Thomas 2007, Kodama et al. 2012).

Fish otoliths are calcium carbonate structures that deposit permanent daily growth bands offering detailed information on age and growth. Otoliths are metabolically inert and not subject to resorption, even during periods of stress (Campana 1983) or starvation (Maillet \& Checkley 1990). Although much otolith chemistry research has focused on chemical identifiers of migratory movements and stock discrimination (Walther \& Limburg 2012), there is significant potential for geochemical indicators of hypoxia exposure to be recorded in otoliths. In particular, otolith manganese $(\mathrm{Mn})$ is a viable geochemical hypoxia proxy (Limburg et al. 2011). Hypoxia alters redox conditions such that Mn oxides are reduced; the reduced forms (primarily $\mathrm{Mn}^{2+}$ but also $\mathrm{Mn}^{3+}$ ) are soluble, and under suboxic/hypoxic conditions, dissolved Mn can be released into the water column (Thamdrup et al. 1994, Slomp et al. 1997) and remain dissolved for several days (Pakhomova et al. 2007). If elevated dissolved Mn leads to increased incorporation of Mn in otoliths, a direct link between residence in hypoxic waters and otolith composition could be employed. However, in order to effectively interpret potential hypoxia proxies such as $\mathrm{Mn} / \mathrm{Ca}$, it is important to validate whether hypoxic stress alone, in the absence of ambient chemical differences, could alter otolith chemistry.
During otolith accretion, aragonite is crystallized onto an organic protein matrix, and dissolved elements from the ambient environment that have passed through several biological barriers (i.e. gill, intestine, blood, and endolymph interfaces) are incorporated into the crystal structure (Campana 1999). While the concentration of some elements may directly reflect water concentrations, there is significant opportunity for physiological regulation of uptake and transport of certain ions at each barrier. Sturrock et al. (2012) employed the hard and soft acid and base theory to describe the behavior of certain metals in seawater and in the blood and endolymph of marine fish. Hard acid cations, such as $\mathrm{Mg}, \mathrm{Sr}, \mathrm{Ca}$, and $\mathrm{Ba}$, exist as free hydrated ions in seawater and in the blood of the fish, so they are more likely to passively diffuse across blood-endolymph membranes, and are more readily accepted into the crystal lattice by substituting for Ca during otolith precipitation. Soft acid cations such as $\mathrm{Cu}, \mathrm{Pb}$, and $\mathrm{Zn}$ are strongly bound to organic ligands in seawater and strongly bind proteins in the blood and thus require more active transport across biological membranes and are susceptible to being rerouted to the liver or actively excreted. The soft acid cations are more likely incorporated with the organic protein matrix of the otolith, or in interstitial spaces of crystal defects. The behavior of intermediate cations, such as Mn, may depend on the environmental or physiological context (Sturrock et al. 2012). The potential influences on blood-endolymph chemistry variation include both environmental (salinity, temperature, dissolved oxygen) and physiological (ontogeny, sex, growth rate) factors (Walther et al. 2010). Understanding whether endogenous (physiological) or exogenous (environmental) processes dominate otolith elemental incorporation is essential for effective interpretations of biogenic proxies.

Here, we examined the elemental chemistry of Atlantic croaker Micropogonias undulatus otoliths in response to hypoxia exposure using both short-term ( $4 \mathrm{wk}$ ) and long-term (10 wk) hypoxia exposure laboratory experiments. This species was chosen because of its extensive use as a model for identifying individual (Thomas \& Rahman 2009, 2012) and populationlevel effects (Craig \& Crowder 2005, Creekmore 2011) of hypoxia exposure. We hypothesized that hypoxic stress will affect element incorporation into the otolith, potentially driven by physiological alteration of blood chemistry through changes in protein and ion content. Experiments were performed in seawater with unmanipulated chemical composition to test the degree of endogenous alteration of otolith chemistry after exposure to hypoxic stress. In the first 
experiment, fish were exposed for 4 wk to constant hypoxia or normoxia (controls), and otoliths were analyzed along the sulcal axis by laser ablation inductively coupled plasma mass spectrometry (LAICP-MS). For the second experiment, fish were exposed for a longer duration of $10 \mathrm{wk}$ to normoxia, constant hypoxia, or periodic alternating hypoxia/ normoxia, and otoliths were analyzed along the ventral axis. Investigating the influence of internal physiological effects on otolith chemistry is essential to discern exogenous environmental signals from endogenous chemical signals contained in otoliths.

\section{MATERIALS AND METHODS}

\section{Laboratory hypoxia experiments}

\section{Experimental fish}

Atlantic croaker (100-110 mm total length, TL; 25-35 g wet mass, M), were caught by shrimp trawl in the Texas (USA) gulf coast by local fisherman and transported to fish holding facilities at the University of Texas Marine Science Institute. Fish were treated with Paracide-F at $170 \mathrm{ppm}$ in seawater for $1 \mathrm{~h}$ to minimize parasite infections and transferred to large indoor recirculating seawater tanks (4727 l) under amient temperature $\left(22-23^{\circ} \mathrm{C}\right)$ and photoperiod (13 h dark:11 h light) conditions for at least 1 mo prior to experimentation. Fish were fed chopped shrimp once a day $\left(3 \% \mathrm{M} \mathrm{d}^{-1}\right)$. At the end of the experiments, fish were sacrificed following guidelines approved by the Institutional Animal Care and Use Committee of the University of Texas at Austin.

4 wk constant hypoxia experiment

Details of the experimental setup were described by Rahman \& Thomas (2012). Briefly, in the hypoxia exposure tanks, the flow of air was reduced through the air flow meter gradually from 100 $80 \%$ to 60 , 40 , and $20 \%$, and finally adjusted until the dissolved oxygen (DO) level reached $1.7 \mathrm{mg} \mathrm{l}^{-1}$, which was achieved within $2 \mathrm{~d}$. A
YSI multiprobe was used to monitor DO, $\mathrm{pH}$, temperature and salinity 3 times daily (Table 1, and see Fig. S1 in the Supplement at www.int-res.com/articles/ suppl/b020p001_supp.pdf). Sodium bicarbonate buffer was added as needed to adjust and maintain $\mathrm{pH}$ between 7.7 and 7.9 during the experiment. At the end of the study, fish TL in $\mathrm{mm}$ and $\mathrm{M}$ in g were measured, and the heads of the experiment subjects containing the otoliths were separated by treatment and frozen until analysis. TL and $M$ data were used to calculate Fulton's condition index, $K=\left(\mathrm{M} / \mathrm{TL}^{3}\right) \times 100$.

10 wk constant and periodic hypoxia experiment

Identical experimental methods as described above were used for the 10 wk hypoxia study; however, an additional treatment of periodic hypoxia exposure was produced by adjusting air flow to the tanks at weekly intervals to expose fish to hypoxia and normoxic conditions every other week. Salinity, temperature, DO concentration, oxygen saturation, and $\mathrm{pH}$ were recorded daily for each of 3 replicate tanks for each treatment (Fig. S1). At the end of the experiment, fish were measured for TL. Fish sex was determined by examining the gonads, and sagittal otoliths were immediately removed, cleaned with ultrapure water, and stored in $1.5 \mathrm{ml}$ polyethylene vials to air dry.

Table 1. Ambient physicochemical parameters of the experimental tanks from the 4 wk experiment (mean \pm SD). Dissolved elemental chemistry data and ambient physicochemical parameters for both control and hypoxia tanks sampled at 2 and $4 \mathrm{wk}$ in the $10 \mathrm{wk}$ experiment. Time series for experimental tank conditions monitored daily can be found in Fig. S1 in the Supplement. DO: dissolved oxygen

\begin{tabular}{|c|c|c|c|c|c|}
\hline \multirow{2}{*}{$\begin{array}{l}\text { Experi- } \\
\text { ment }\end{array}$} & \multirow{2}{*}{$\begin{array}{l}\text { Physicochemical } \\
\text { parameter }\end{array}$} & \multicolumn{4}{|c|}{ Experimental tank/sampling time } \\
\hline & & \multicolumn{2}{|c|}{ Control } & \multicolumn{2}{|c|}{ Hypoxia } \\
\hline \multirow[t]{7}{*}{$4 \mathrm{wk}$} & Salinity (ppt) & \multicolumn{2}{|c|}{$32.50 \pm 0.04$} & \multicolumn{2}{|c|}{$32.55 \pm 0.07$} \\
\hline & Temperature $\left({ }^{\circ} \mathrm{C}\right)$ & \multicolumn{2}{|c|}{$21.87 \pm 0.12$} & \multicolumn{2}{|c|}{$21.85 \pm 0.07$} \\
\hline & DO (\%) & \multicolumn{2}{|c|}{$99.84 \pm 1.17$} & \multicolumn{2}{|c|}{$26.56 \pm 0.81$} \\
\hline & $\mathrm{DO}\left(\mathrm{mg} \mathrm{l}^{-1}\right)$ & \multicolumn{2}{|c|}{$7.27 \pm 0.12$} & \multicolumn{2}{|c|}{$1.80 \pm 0.06$} \\
\hline & $\mathrm{pH}$ & \multicolumn{2}{|c|}{$7.69 \pm 0.02$} & \multicolumn{2}{|c|}{$7.55 \pm 0.01$} \\
\hline & & \multicolumn{2}{|c|}{$2 \mathrm{wk}$} & \multicolumn{2}{|c|}{$4 \mathrm{wk}$} \\
\hline & & Control & Hypoxia & Control & Hypoxia \\
\hline \multirow[t]{10}{*}{$10 \mathrm{wk}$} & $\mathrm{Sr}: \mathrm{Ca}\left(\mathrm{mmol} \mathrm{mol}{ }^{-1}\right)$ & 8.21 & 8.21 & 8.04 & 8.07 \\
\hline & $\mathrm{Ba}: \mathrm{Ca}\left(\mu \mathrm{mol} \mathrm{mol}{ }^{-1}\right)$ & 12.52 & 13.16 & 27.9 & 28.89 \\
\hline & Mn:Ca $\left(\mu \mathrm{mol} \mathrm{mol}{ }^{-1}\right)$ & 6.8 & 13.4 & 7.02 & 9.53 \\
\hline & $\mathrm{Mg}: \mathrm{Ca}\left(\mathrm{mol} \mathrm{mol}{ }^{-1}\right)$ & 5.12 & 5.14 & 5 & 5.06 \\
\hline & $\mathrm{Na}: \mathrm{Ca}\left(\mathrm{mmol} \mathrm{mol}{ }^{-1}\right)$ & 45.07 & 45.19 & 43.88 & 44.63 \\
\hline & Salinity (ppt) & 39.04 & 39.08 & 34.49 & 34.79 \\
\hline & Temperature $\left({ }^{\circ} \mathrm{C}\right)$ & 22.3 & 22.3 & 22.1 & 22 \\
\hline & DO $(\%)$ & 76 & 23.3 & 82.4 & 26.4 \\
\hline & $\mathrm{DO}\left(\mathrm{mg} \mathrm{l}^{-1}\right)$ & 5.34 & 1.64 & 5.97 & 1.85 \\
\hline & $\mathrm{pH}$ & 7.35 & 7.44 & 7.53 & 7.45 \\
\hline
\end{tabular}




\section{Otolith preparation and chemical analysis}

4 wk exposure study

Otoliths were weighed to the nearest $0.001 \mathrm{~g}$, and no difference in mass was detected between left and right otoliths (paired $t$-test, $\mathrm{df}=57, t=0.097, \mathrm{p}=$ 0.9225). Therefore, either the left or right otolith was randomly chosen for analysis. Otoliths $(\mathrm{N}=46)$ were embedded in Epoxi-Cure resin, sectioned in the transverse plane using a low-speed diamond blade saw, mounted on petrographic slides with Crystal Bond thermoplastic cement, and polished with lapping film (30 and $3 \mu \mathrm{m}$ ) to expose the core. Polished sections were then transferred to new petrographic slides (6 to 7 sections per slide) and sonicated in ultrapure water $(18.2 \mathrm{~m} \Omega) 3$ times for $5 \mathrm{~min}$ and dried in a class 100 laminar flow hood before analysis.

\section{0 wk exposure study}

Indium chloride (30 ppm) was added to the EpoxiCure resin and Crystal Bond embedding/mounting media to serve as an elemental indicator during the laser analysis, thus allowing precise determination of the otolith edge/resin interface in the data set. Left otoliths $(\mathrm{N}=72)$ were weighed, embedded, sectioned, polished, cleaned, and air-dried as described above.

LA-ICP-MS analyses were conducted at the University of Texas Jackson School of Geosciences, Austin, Texas. An Aligent 7500ce ICP-Q-MS coupled to a New Wave UP 193-FX laser with a $26 \mu$ m laser spot diameter, $30 \%$ power (mean \pm SD: $4.37 \pm 0.16 \mathrm{~J}$ $\mathrm{cm}^{-2}$ ), and $5 \mu \mathrm{m} \mathrm{s}^{-1}$ scan speed was used to quantify ${ }^{43} \mathrm{Ca}_{1}{ }^{88} \mathrm{Sr}_{,}{ }^{55} \mathrm{Mn},{ }^{24} \mathrm{Mg},{ }^{23} \mathrm{Na}$, and ${ }^{137} \mathrm{Ba}$ from transects ablated across otoliths following an initial pre-ablation (35 $\mu \mathrm{m}$ spot diameter, $10 \%$ power, $25 \mu \mathrm{m} \mathrm{s}^{-1}$ scan speed) to remove potential surface contamination. MACS-3 calcium carbonate and NIST 612 glass certified standards were run at the beginning and after every $60 \mathrm{~min}$ of analysis to convert raw intensity counts to molar concentrations (using MACS-3), correct for instrument drift, and assess analytical precision (with NIST 612). Elemental intensity count data were converted to concentrations using the Trace Elements IS Data Reduction Scheme in the software Iolite that uses calcium (as $37.69 \mathrm{wt} \%$ in aragonite) as an internal standard (Paton et al. 2011) and then converted to molar ratios. Relative standard deviations (RSDs) based on repeated measurements of the NIST 612 standard for the 4 wk data collected October
2010 over 2 d were: $\mathrm{Sr}=3.0 \%, \mathrm{Ba}=5.4 \%, \mathrm{Mn}=$ $7.3 \%, \mathrm{Mg}=7.5 \%$, and $\mathrm{Na}=12.9 \%$; while the RSDs for the $10 \mathrm{wk}$ experimental fish analyzed in December 2012 over 4 d were: $\mathrm{Sr}=10.2 \%, \mathrm{Ba}=11 \%, \mathrm{Mn}=$ $19.6 \%, \mathrm{Mg}=10.7 \%$, and $\mathrm{Na}=15.7 \%$.

For the 4 wk study otoliths, laser transects were initiated at the otolith core and run parallel to the sulcal groove to the otolith edge, obtaining a lifetime elemental profile for each otolith. For the 10 wk study, the laser was run from the core to the edge along the ventral otolith axis, which displays wider growth increments than the sulcal axis (Fig. S2a in the Supplement). Elemental concentrations were only compared within a given experiment using similar laser transect paths (treatments versus controls), given the potential for different concentrations obtained from different ablation axes. To estimate otolith precipitation rates, a subset of fish $(\mathrm{N}=4)$ were bathed $24 \mathrm{~h}$ in calcium-staining alizarin red solution $\left(400 \mathrm{mg} \mathrm{l}^{-1}\right.$ ) and held for 4 or $10 \mathrm{wk}$ in the same size tank and fed the same food as experimental fish in normoxic conditions. At the end of the holding period, the fish were sacrificed and otoliths were embedded, sectioned, and polished as described above. The stained otolith sections were then viewed with fluorescent light to capture digital images to measure the distance between stained growth increment and otolith edge using ImageJ software to estimate otolith precipitation rates $\left(\mu \mathrm{m} \mathrm{d}^{-1}\right)$ along the sulcal and ventral growth axes (Fig. S2b,c, Table S1 in the Supplement). Mean otolith precipitation rates for the fish held for $4 \mathrm{wk}$ and analyzed along the sulcal groove was $1.17 \mu \mathrm{m} \mathrm{d}^{-1}$, while those otoliths from the $10 \mathrm{wk}$ study lasered along the ventral axis displayed mean precipitation rates of $1.35 \mu \mathrm{m} \mathrm{d}^{-1}$ (Fig. S2d). All fish tagged in the alizarin study lost between 6 and $14 \%$ body weight due to poor feeding, and thus our estimates of otolith precipitation are conservative estimates to ensure that no pre-experimental aragonite was included in treatment comparisons (Table S1). The otolith chemistry data that were precipitated during the experiment were extracted from each fish otolith time series and averaged together for analysis.

\section{Collection and analysis of water samples}

During the 10 wk experiment, water samples were collected from experimental tanks at 2 and 4 wk in order to assess variation in water chemistry. Samples were pumped from the bottom of a control and hypoxic tank using acid-washed Teflon tubing and a peristaltic pump (Masterflex). The sample water was 
filtered with 0.45 and $0.2 \mu \mathrm{m}$ polytetrafluoroethylene filters in sequence with acid-washed $30 \mathrm{ml}$ syringes to remove any particulate matter and retain dissolved fractions and immediately acidified to $\mathrm{pH}<2$ with trace metal grade nitric acid into acid-washed $30 \mathrm{ml}$ low-density polyethylene Nalgene bottles to be stored at $4{ }^{\circ} \mathrm{C}$ until analysis. Water samples were analyzed for trace elements using solution-based ICPMS at the University of Texas Jackson School of Geosciences. Samples were diluted $100 \times$ with $2 \%$ trace metal grade $\mathrm{HNO}_{3}$, and a subset of samples was spiked with matrix-matched solutions to assess recoveries. Replicated blanks and certified reference standards were used to convert isotope counts to concentrations and then converted to element:calcium ratios. Mean spike recoveries ( $\mathrm{N}=6$ spiked samples) were, means $\pm \mathrm{SD}: \mathrm{Sr}=95.9 \pm 0.4 \%, \mathrm{Ba}=95.4 \pm 0.4$, $\mathrm{Ca}=97.0 \pm 1.7 \mathrm{Mn}=93.8 \pm 0.3, \mathrm{Mg}=87.9 \pm 8.7, \mathrm{Na}=$ $67.9 \pm 23.7$.

\section{Data analysis}

Student's $t$-tests were used to compare condition factor $(K)$ and otolith mass between control and constant hypoxia-exposed fish from the 4 and $10 \mathrm{wk}$ experiments. Elemental otolith data were examined for normality and homoscedasticity, and a natural log transformation was performed for those elements that did not meet assumptions $(\mathrm{Ba}: \mathrm{Ca}$, $\mathrm{Mg}: \mathrm{Ca}$, and $\mathrm{Mn}: \mathrm{Ca})$. We found a significant difference in otolith mass between control and hypoxiaexposed fish in the $4 \mathrm{wk}$ exposure study ( $t$-test, $t=$ 2.596, $\mathrm{df}=56, \mathrm{p}=0.012)$; therefore, a 1-way ANCOVA was used to compare elemental ratios between control and hypoxia-exposed fish, with otolith mass as a covariate.

Similarly, for the $10 \mathrm{wk}$ exposure study, mean experimental otolith elemental ratios (Ba:Ca, $\mathrm{Mn}: \mathrm{Ca}$ ) were log-transformed to meet assumptions of normality and equal variance. Initially, a generalized linear model was performed to test the effect of Treatment, Sex, Treatment $\times$ Sex interaction, with Tank nested within Treatment $\times$ Sex. There was no significant effect of tank on otolith elemental ratios, so the 3 replicate tanks per treatment were pooled together to run a 2-way ANOVA to examine the effect of Treatment, Sex, and Treatment $\times$ Sex on otolith elemental ratios and otolith mass. When a significant factor effect was detected with the 2-way ANOVA, Holm-Sidak multiple comparison methods were used to determine which treatment or sex was different by pooling data within a treatment (for
Ba:Ca and Mg:Ca) or sex (for Mn:Ca). All statistical analyses were performed using SYSTAT 12.

\section{RESULTS}

\section{4 wk exposure}

The condition factor $(K)$ and otolith mass of hypoxia-exposed fish were significantly reduced compared to the control $(K: t=4.207, \mathrm{df}=61, \mathrm{p}<$ 0.001; otolith mass: $t=2.596, \mathrm{df}=56, \mathrm{p}=0.012$; Fig. 1). However, no significant difference in otolith $\mathrm{Sr}: \mathrm{Ca}, \mathrm{Ba}: \mathrm{Ca}, \mathrm{Mn}: \mathrm{Ca}, \mathrm{Mg}: \mathrm{Ca}$, or $\mathrm{Na}: \mathrm{Ca}$ ratios were detected between control and hypoxia-exposed fish when accounting for otolith mass variation using ANCOVA (Fig. 1, Table 2).

\section{0 wk exposure}

The dissolved elemental chemistry of the experimental tank water displayed limited variability for all elements except $\mathrm{Ba}: \mathrm{Ca}$ and $\mathrm{Mn}: \mathrm{Ca}$ ratios. $\mathrm{Ba}: \mathrm{Ca}$ molar ratios increased almost 2-fold from Week 2 to Week 4 in both control and hypoxia treatment tanks, which was accompanied by a decrease in salinity of approximately 5 ppt (Table 1 ). The $\mathrm{Mn}$ :Ca ratio was elevated in the hypoxic tanks, which had $50 \%$ less dissolved $\mathrm{O}_{2}$ than the control tanks by $6.6 \mathrm{\mu mol} \mathrm{mol}^{-1}$ at $2 \mathrm{wk}$ and $2.5 \mu \mathrm{mol} \mathrm{mol}{ }^{-1}$ at $4 \mathrm{wk}$ (Table 1). In contrast to the 4 wk study, otolith mass was not different between control or hypoxia-exposed fish (Table $3)$. $K$ of fish exposed to constant hypoxia was significantly decreased compared to controls $(t=3.234, \mathrm{df}=$ $45, \mathrm{p}=0.0023$; Fig. 1). Similar to the results of the 4 wk exposure study, there were no significant differences in otolith $\mathrm{Sr}: \mathrm{Ca}, \mathrm{Ba}: \mathrm{Ca}, \mathrm{Mn}: \mathrm{Ca}, \mathrm{Mg}: \mathrm{Ca}$, or $\mathrm{Na}: \mathrm{Ca}$ ratios between the control and fish exposed to constant hypoxia for $10 \mathrm{wk}$ (Fig. 1). Only minor treatment and sex differences in the molar ratios of elements were observed in the periodic hypoxia treatment, varying less than $20 \%$, whereas molar ratios of $\mathrm{Sr}: \mathrm{Ca}, \mathrm{Ba}: \mathrm{Ca}, \mathrm{Mg}: \mathrm{Ca}$, and $\mathrm{Zn}: \mathrm{Ca}$ in Atlantic croaker otoliths have been found to vary 60 to $90 \%$ in environmental samples collected from Chesapeake Bay and Pamlico Sound, North Carolina, USA (Thorrold et al. 1997, Thorrold \& Shuttleworth 2000). Interestingly, a significant treatment effect was detected for otolith $\mathrm{Ba}: \mathrm{Ca}$ and $\mathrm{Mg}: \mathrm{Ca}$ (Table 4), with post hoc tests revealing that $\mathrm{Ba}: \mathrm{Ca}$ and $\mathrm{Mg}$ :Ca ratios were significantly reduced in the periodic treatment when males and females were pooled (Fig. 2). A 

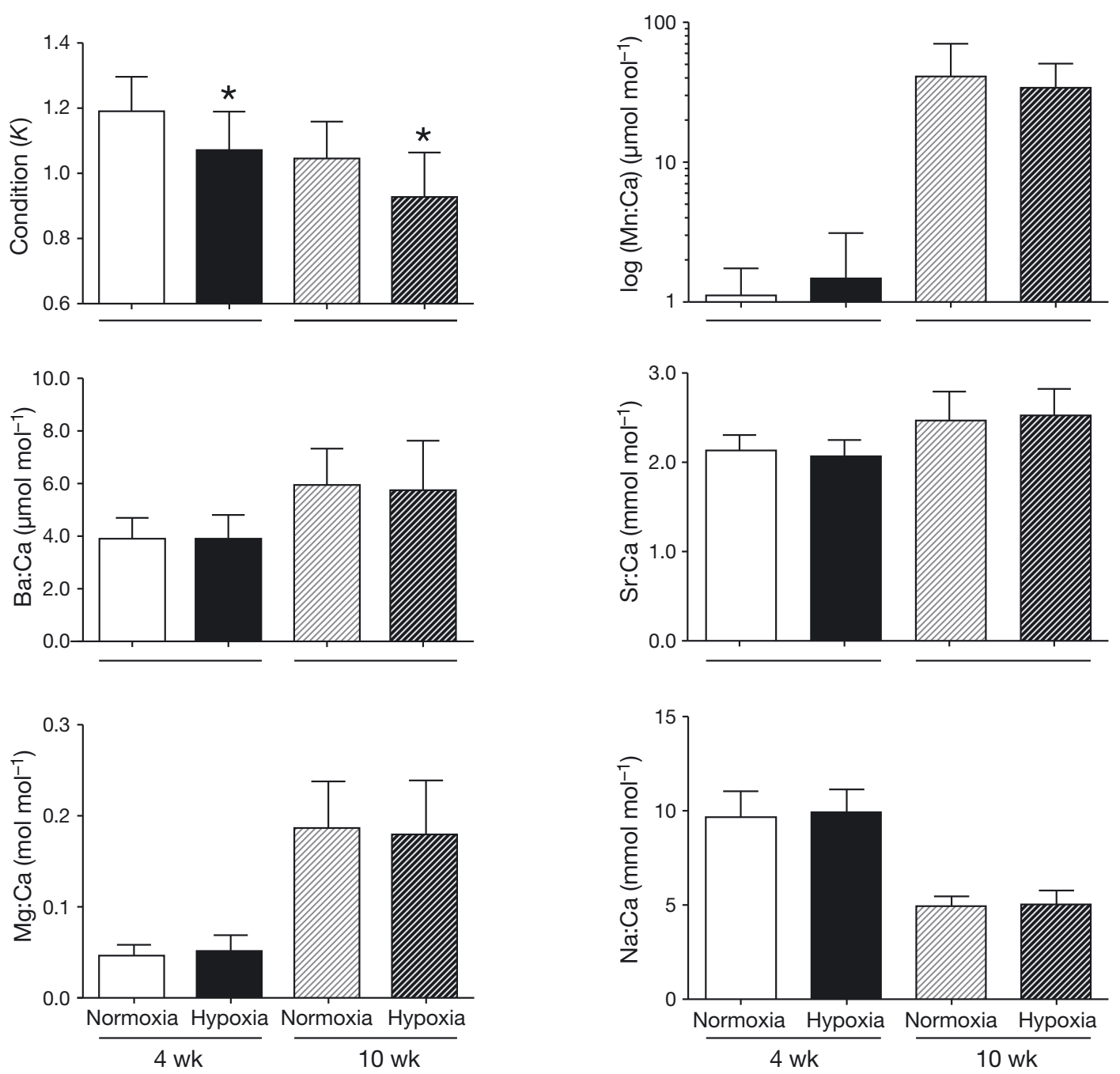

Fig. 1. Micropogonias undulatus. Fulton's condition index ( $K_{;}$see 'Materials and methods' for calculation) and otolith element:Ca ratios of $\mathrm{Sr}: \mathrm{Ca}, \mathrm{Ba}: \mathrm{Ca}, \mathrm{Mn}: \mathrm{Ca}, \mathrm{Mg}: \mathrm{Ca}$, and Na:Ca for Atlantic croaker exposed for either 4 or 10 wk to normoxia (control) or constant hypoxia. Error bars indicate standard deviation and * indicates significant difference $(p<0.05)$ by Student's $t$ test. Note that differences in elemental concentrations between the 4 and $10 \mathrm{wk}$ experiments were due to ablations on different otolith growth axes

significant interaction between treatment and sex was detected for both otolith $\mathrm{Sr}: \mathrm{Ca}$ and Na:Ca ratios (Table 4). For otolith $\mathrm{Sr}: \mathrm{Ca}$, females had decreased ratios in the control treatment, and males had decreased ratios in the periodic hypoxia treatment, but we found no sex differences in the constant hypoxia treatment (Fig. 2). Otolith Na:Ca was significantly lower in males in the periodic hypoxia treatment, but there were no sex differences in the control or constant hypoxia treatments (Fig. 2). Sex had a significant effect on otolith $\mathrm{Mn}: \mathrm{Ca}$ when all treatments were pooled (Table 4), with females having higher ratios than males (Fig. 2).
Table 2. One-way ANCOVA results with otolith mass as covariate for Atlantic croaker exposed 4 wk to control or hypoxic conditions

\begin{tabular}{|llccccc|}
\hline Variable & Effect & Type III SS & df & MS & $F$ & $p$ \\
\hline Sr:Ca & Treatment & 0.054 & 1 & 0.054 & 1.659 & 0.205 \\
& Otolith mass & 0.006 & 1 & 0.006 & 0.176 & 0.677 \\
$\ln (\mathrm{Ba}: \mathrm{Ca})$ & Treatment & 0.000 & 1 & 0.000 & 0.049 & 0.827 \\
& Otolith mass & 0.003 & 1 & 0.003 & 0.299 & 0.588 \\
$\ln (\mathrm{Mn}: \mathrm{Ca})$ & Treatment & 0.020 & 1 & 0.020 & 0.345 & 0.560 \\
& Otolith mass & 0.073 & 1 & 0.073 & 1.256 & 0.269 \\
$\ln (\mathrm{Mg}: \mathrm{Ca})$ & Treatment & 0.012 & 1 & 0.012 & 0.794 & 0.378 \\
& Otolith mass & 0.000 & 1 & 0.000 & 0.011 & 0.918 \\
$\mathrm{Na}: \mathrm{Ca}$ & Treatment & 0.901 & 1 & 0.901 & 0.534 & 0.469 \\
& Otolith mass & 0.160 & 1 & 0.160 & 0.095 & 0.759 \\
\hline
\end{tabular}


Table 3. Micropogonias undulatus. Sample size (N), total length (TL), and otolith mass of Atlantic croakers exposed 4 or 10 wk to control, constant hypoxia, or periodic hypoxia experimental treatments (mean $\pm \mathrm{SD}) .{ }^{*}$ Significant difference $(\mathrm{p}<0.05)$ by Student's $t$-test. -: not applicable

\begin{tabular}{|c|c|c|c|c|c|c|}
\hline \multirow[t]{2}{*}{ Treatment } & \multicolumn{3}{|c|}{$4 \mathrm{wk}$} & \multirow{2}{*}{$\overline{\mathrm{N}}$} & $-10 \mathrm{wk}$ & \multirow[b]{2}{*}{ Otolith mass (mg) } \\
\hline & $\mathrm{N}$ & $\mathrm{TL}(\mathrm{cm})$ & Otolith mass (mg) & & $\mathrm{TL}(\mathrm{cm})$ & \\
\hline Control & 28 & $15.18 \pm 0.58$ & $115.89 \pm 9.25$ & 24 & $15.69 \pm 0.54$ & $125.92 \pm 10.45$ \\
\hline Constant hypoxia & 30 & $15.00 \pm 0.56$ & $109.88 \pm 8.38^{*}$ & 23 & $15.50 \pm 0.60$ & $124.26 \pm 10.26$ \\
\hline Periodic hypoxia & - & - & - & 24 & $15.796 \pm 0.59$ & $126.42 \pm 9.151$ \\
\hline
\end{tabular}

Table 4. Two-way ANOVA investigating effects on Atlantic croaker otolith mass and elemental ratios, of Treatment (control, constant hypoxia, periodic hypoxia), Sex (male, female), and the interaction of Treatment $\times$ Sex in the 10 wk hypoxia study. Significant effects $(\mathrm{p}<$ 0.05) are shown in bold

\begin{tabular}{|c|c|c|c|c|c|}
\hline Variable & Effect & $\mathrm{df}$ & MS & $F$ & $\mathrm{p}$ \\
\hline \multirow[t]{3}{*}{ Otolith mass } & Treatment & 2 & 32.871 & 0.323 & 0.725 \\
\hline & Sex & 1 & 125.343 & 1.232 & 0.271 \\
\hline & Treatment $\times$ Sex & 2 & 6.123 & 0.0602 & 0.942 \\
\hline \multirow[t]{3}{*}{$\ln (\mathrm{Mn}: \mathrm{Ca})$} & Treatment & 2 & 0.0369 & 0.628 & 0.537 \\
\hline & Sex & 1 & 0.242 & 4.117 & 0.047 \\
\hline & Treatment $\times$ Sex & 2 & 0.0247 & 0.42 & 0.659 \\
\hline \multirow[t]{3}{*}{$\mathrm{Mg}: \mathrm{Ca}$} & Treatment & 2 & 0.0131 & 4.334 & 0.017 \\
\hline & Sex & 1 & 0.00311 & 1.032 & 0.313 \\
\hline & Treatment $\times$ Sex & 2 & 0.00104 & 0.346 & 0.709 \\
\hline \multirow[t]{3}{*}{$\mathrm{Sr}: \mathrm{Ca}$} & Treatment & 2 & 0.0564 & 0.729 & 0.487 \\
\hline & Sex & 1 & 0.00167 & 0.0215 & 0.884 \\
\hline & Treatment $\times$ Sex & 2 & 0.451 & 5.822 & 0.005 \\
\hline \multirow[t]{3}{*}{$\ln (\mathrm{Ba}: \mathrm{Ca})$} & Treatment & 2 & 0.0823 & 5.717 & 0.005 \\
\hline & Sex & 1 & 0.00655 & 0.455 & 0.503 \\
\hline & Treatment $\times$ Sex & 2 & 0.0101 & 0.702 & 0.499 \\
\hline \multirow[t]{3}{*}{$\mathrm{Na}: \mathrm{Ca}$} & Treatment & 2 & 0.0357 & 0.105 & 0.9 \\
\hline & Sex & 1 & 0.312 & 0.919 & 0.341 \\
\hline & Treatment $\times$ Sex & 2 & 1.228 & 3.621 & 0.032 \\
\hline
\end{tabular}

\section{DISCUSSION}

We have demonstrated with 2 independent controlled laboratory experiments that physiological stress associated with short- and long-term constant sublethal hypoxic exposure has minimal influence on the otolith chemistry of the hypoxia-tolerant teleost Atlantic croaker. In the first experiment, after $4 \mathrm{wk}$ of constant hypoxia exposure, fish condition was significantly reduced, indicating that somatic growth was impaired; however, elemental ratios did not differ between control and hypoxiaexposed fish. Similarly, after $10 \mathrm{wk}$ of constant hypoxia exposure, the otolith chemistries of both male and female croakers were not different from controls, although condition factors of hypoxic fish were decreased, which lends further support to our initial finding. The variation in otolith $\mathrm{Sr}: \mathrm{Ca}, \mathrm{Ba}: \mathrm{Ca}, \mathrm{Mg}: \mathrm{Ca}$, and $\mathrm{Na} \mathrm{Ca}$ ratios that was detected in response to the periodic hypoxia treatment was small compared to variation seen in field studies. In our study, the variation in otolith element ratios between control and periodic hypoxia treatments was only $2 \mu \mathrm{mol} \mathrm{mol}{ }^{-1}$ for $\mathrm{Ba}: \mathrm{Ca}, 0.25 \mathrm{mmol} \mathrm{mol}^{-1}$ for $\mathrm{Sr}: \mathrm{Ca}, 20 \mu \mathrm{mol}$

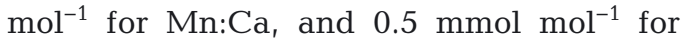
$\mathrm{Na}$ :Ca. In contrast, Thorrold \& Shuttleworth (2000) reported 2 to 10 times the variation found in our study of $4 \mu \mathrm{mol} \mathrm{mol}{ }^{-1}$ for Ba: $\mathrm{Ca}, 2.5 \mathrm{mmol} \mathrm{mol}^{-1}$ for $\mathrm{Sr}: \mathrm{Ca}$, and $40 \mu \mathrm{mol}$ $\mathrm{mol}^{-1}$ for $\mathrm{Mn}: \mathrm{Ca}$ in otoliths of Atlantic croaker collected from northeastern estuaries. These data suggest that environmental factors dominate element incorporation with minimal influence from physiological stress.

\section{Redox-sensitive otolith proxies}

The most promising geochemical proxy for hypoxia, Mn:Ca ratio, did not show statistically significant variation by treatment. The experimental tank water from the constant hypoxic tanks did contain higher dissolved $\mathrm{Mn}: \mathrm{Ca}$, perhaps due to lower oxygen saturation allowing $\mathrm{Mn}^{2+}$ to remain dissolved, but these differences were relatively small compared to field observations of dissolved $\mathrm{Mn}: \mathrm{Ca}$, which can vary over orders of magnitude in both space and time (Slowey \& Hood 1971, Statham et al. 2005). Only 2 controlled laboratory studies have directly examined otolith composition following addition of dissolved $\mathrm{Mn}$ to water, and neither reported positive relationships (Elsdon \& Gillanders 2003, Miller 2009). In contrast, several field studies have reported positive correlations between ambient dissolved Mn:Ca and otolith Mn:Ca (Forrester 2005, Dorval et al. 2007, Mohan et al. 2012). Additional 

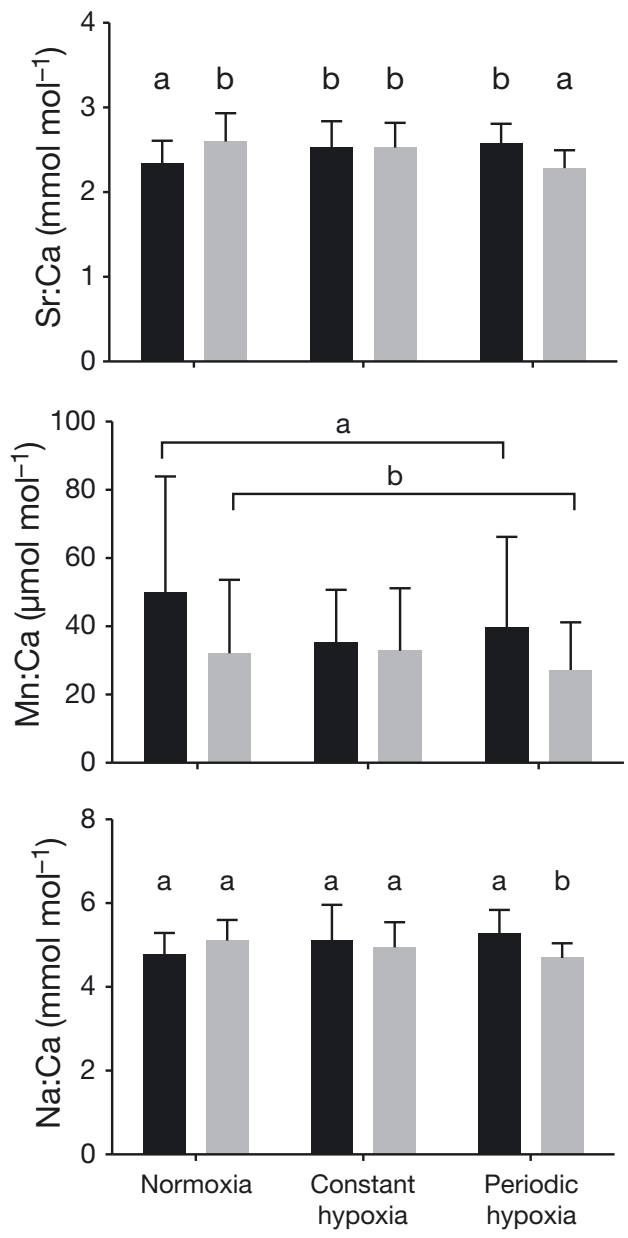

field studies have attributed elevated otolith $\mathrm{Mn}$ to hypoxic redox conditions in Pamlico Sound (Thorrold \& Shuttleworth 2000), Chesapeake Bay (Dorval et al. 2007), and the Baltic Sea (Limburg et al. 2011). The mechanism of $\mathrm{Mn}$ incorporation into otoliths is unclear, but substitution with $\mathrm{Ca}^{2+}$ ions in the aragonite crystal lattice has been suggested, as Mn has not been detected bound to proteins in cod otoliths (Miller et al. 2006). As discussed by Sturrock et al. (2012), the chemical behavior of $\mathrm{Mn}^{2+}$ is intermediate between hard acids/bases and soft acids/bases, meaning it can exist in the plasma and endolymph in both free and bound forms. We did detect a slight statistically significant effect of sex $(p=0.047)$ on otolith $\mathrm{Mn}: \mathrm{Ca}$, with higher ratios in females, but both males and females in the constant hypoxia treatment were similar. Unlike the other elements we investigated that tend to vary with salinity, dissolved $\mathrm{Mn}: \mathrm{Ca}$ will flux out of sediments in dissolved form during lowoxygen events, thus the non-effect of hypoxia on otolith Mn:Ca observed in this experiment is perhaps due to lack of sedimentary supply of $\mathrm{Mn}^{2+}$. The small variation in dissolved $\mathrm{Mn}$ :Ca between control and
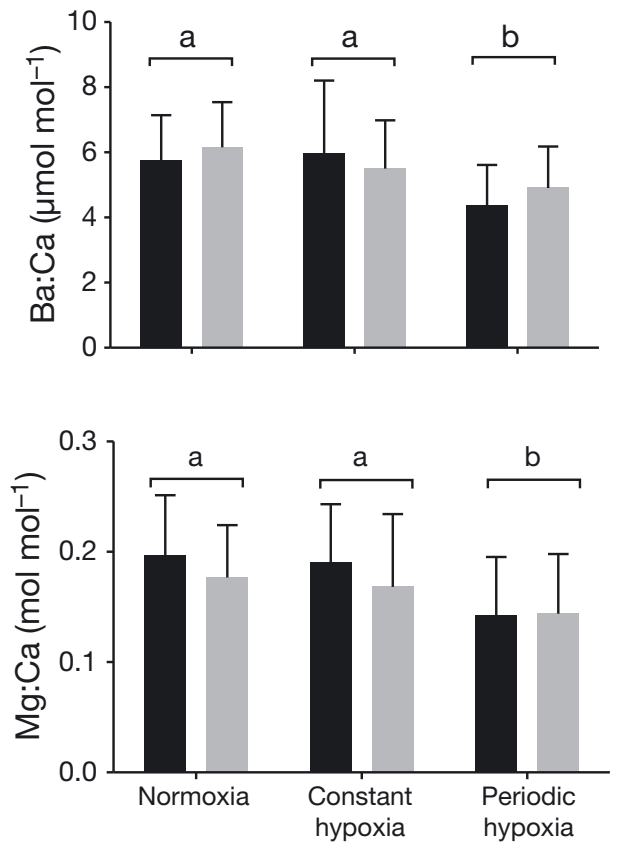

Fig. 2. Micropogonias undulatus. Otolith element:Ca ratios of $\mathrm{Sr}: \mathrm{Ca}, \mathrm{Ba}: \mathrm{Ca}, \mathrm{Mn}: \mathrm{Ca}, \mathrm{Mg}: \mathrm{Ca}$, and $\mathrm{Na}: \mathrm{Ca}$ of females (black bars) and males (gray bars) exposed for 10 wk to normoxia (control), constant hypoxia, or periodic hypoxia. Error bars indicate standard deviation, with different lowercase letters above bars indicating significant $(\mathrm{p}<0.05)$ post hoc comparisons using HolmSidak methods after 2-way ANOVA examining main effects, with brackets above bars indicating pooled data

hypoxic experimental tank water was not enough to induce changes in otolith chemistry, as neither was the physiological effect of hypoxic stress. These results, along with other field studies that have measured ambient dissolved Mn (Dorval et al. 2007, Limburg et al. 2011, Mohan et al. 2012), support the hypothesis that variation in otolith $\mathrm{Mn}: \mathrm{Ca}$ is strongly driven by exogenous, environmental dissolved ambient $\mathrm{Mn}^{2+}$ variability that may be linked to sediment redox biogeochemistry.

\section{Effects of sex and stress on otolith chemistry}

Many studies have documented intrinsic vital effects on otolith chemistry, but few have examined differences between male and female fish. Kalish (1991) examined seasonal variation in the chemistry of the blood plasma, endolymph, and otoliths of male and female bearded rock cod, and also investigated changes in the protein content of the blood. Seasonal variation in the trace element chemistry of the endolymph was related to changes in the protein content 
of the blood plasma in response to gonad development. It was hypothesized that as fish invest energy into reproduction, more calcium-binding proteins, such as the egg-yolk precursor vitellogenin, will be present in the blood and endolymph, which reduces the amount of free $\mathrm{Ca}$ available for otolith accretion resulting in increases in other trace metal impurities such as Sr (Kalish 1991). Earlier studies related otolith Sr:Ca to changes in temperature (Radtke 1989) or somatic growth rate (Sadovy \& Severin 1992) without considering the effect of gonad development that is initiated by temperature changes and results in reduced somatic growth (Kalish 1991). The significant interaction between sex and treatment that we detected for $\mathrm{Sr}: \mathrm{Ca}$ and $\mathrm{Na}$ :Ca ratios may have been the product of differential gonad investment in addition to the stress of the periodic hypoxia treatment.

Few other studies have examined the effects of stress on otolith chemistry (Kalish 1992) or blood and endolymph chemistry (Payan et al. 2004a). Thermal and osmotic stress resulted in low condition factors, a decrease in otolith $\mathrm{Na}: \mathrm{Ca}$, and an increase in otolith Sr:Ca in Australian salmon (Kalish 1992). Rainbow trout that were stressed with $\mathrm{Cl}_{2}$ gas exhibited decreased $\mathrm{Na}^{+}$and $\mathrm{Cl}^{-}$in the blood plasma and endolymph and increased proteins in the proximal endolymph, but no changes in total Ca (Payan et al. 2004a). The stress-induced changes in endolymph chemistry also produced a 'check' mark and caused a reduction in otolith growth rate. Growth rate effects on otolith chemistry have been regarded as kinetic or physiological (Walther et al. 2010). Kinetic effects are controlled by the calcification rate of the otolith and can either result in increased element:Ca ratios if more trace elements get entrapped within the crystal during rapid calcification due to increased crystal defects (Gaetani \& Cohen 2006), or decreased element:Ca if higher supplies of $\mathrm{Ca}^{2+}$ in the endolymph dilutes the concentration of other trace elements in the calcifying fluid (Sinclair 2005). Physiological effects are mediated by metal-binding protein levels in the endolymph, which is coupled to somatic growth and affects the availability of free ions to be incorporated into the otolith. Otolith $\mathrm{Mg}$ :Ca was correlated with somatic growth and otolith precipitation rates in spot (Bath Martin \& Thorrold 2005) and in Chinook salmon (Miller 2011), and Mg is subject to strong physiological regulation in fish (Woodcock et al. 2012). The stressful periodic hypoxia decreased otolith $\mathrm{Mg}: \mathrm{Ca}$ as would be expected if $\mathrm{Mg}$ is under endogenous control, but otolith $\mathrm{Ba}: \mathrm{Ca}$ also decreased. In many euryhaline species, otolith $\mathrm{Ba}: \mathrm{Ca}$ typically displays positive relationships with ambient dissolved $\mathrm{Ba}$, as observed in both controlled lab experiments (Bath et al. 2000, Elsdon \& Gillanders 2002, 2003, 2004, 2005, Bath Martin \& Thorrold 2005, Walther \& Thorrold 2006, Miller 2009), and field studies (Dorval et al. 2007, Walther \& Thorrold 2008, Mohan et al. 2012). Some studies have found an effect of somatic/otolith growth on otolith Ba:Ca (Walther et al. 2010, Miller 2011), or temperature effects which can be related to growth (Elsdon \& Gillanders 2002, 2004), while others have detected no growth/temperature effects (Bath et al. 2000, Bath Martin \& Thorrold 2005, Bath Martin \& Wuenschel 2006). More work is needed to assess the potential effects of stress and growth on otolith $\mathrm{Mg}: \mathrm{Ca}$ and $\mathrm{Ba}: \mathrm{Ca}$ ratios.

Interestingly, the periodic hypoxia treatment did result in significant Sex $\times$ Treatment interactions for otolith $\mathrm{Sr}: \mathrm{Ca}$ and $\mathrm{Na}: \mathrm{Ca}$ ratios and also decreased both otolith $\mathrm{Ba}: \mathrm{Ca}$ and $\mathrm{Mg}: \mathrm{Ca}$ ratios, perhaps because alternating between hypoxic and normoxic conditions is more physiologically stressful than remaining in constant hypoxic conditions. Hypoxiatolerant species exhibit 3 specialized adaptations when they encounter low-oxygen conditions: (1) metabolic suppression, (2) tolerance of $\mathrm{pH}$ and ionic disturbances, and (3) ability to avoid free-radical injury during reoxygenation (Bickler \& Buck 2007). Fish exposed to constant hypoxia would only need to enact the first 2 defense mechanisms, but those fish exposed to alternating weeks of hypoxia and normoxia would need to utilize all 3 mechanisms and at weekly intervals. The periodic hypoxia treatment did not significantly inhibit somatic growth, since condition factors did not differ from control fish, but otolith $\mathrm{Ba}: \mathrm{Ca}$ and $\mathrm{Mg}: \mathrm{Ca}$ were decreased. Dissolved $\mathrm{Mg}: \mathrm{Ca}$, $\mathrm{Sr}: \mathrm{Ca}, \mathrm{Ba}: \mathrm{Ca}$, and $\mathrm{Na}$ :Ca ratios were similar between control and constant hypoxia tanks throughout the experiment. Only dissolved Mn:Ca was different between control and hypoxic tanks, but a difference of $7 \mu \mathrm{mol} \mathrm{mol}^{-1}$ is very minor compared to field observations of dissolved $\mathrm{Mn}: \mathrm{Ca}$ in the northern Gulf of Mexico, which can vary over $100 \mu \mathrm{mol} \mathrm{mol}^{-1}$ at low $\mathrm{O}_{2}$ levels (J. Mohan unpublished data), and Mn can be elevated several orders of magnitude in coastal regions compared to offshore Gulf waters (Slowey \& Hood 1971).

\section{Chemistry differences in otolith growth axis}

We found differences in elemental chemistry between the sulcal and ventral axes of the croaker otoliths, as expected. Compared to the sulcal axis, the longer ventral axis exhibited approximately $1.5 \times, 4 \times$, 
and 40× higher values for $\mathrm{Ba}: \mathrm{Ca}, \mathrm{Mg}: \mathrm{Ca}, \mathrm{Mn}: \mathrm{Ca}$ ratios, respectively. Only $\mathrm{Na}$ :Ca was increased 2-fold on the sulcal axis, while Sr:Ca was similar between both axes. These patterns may have arisen simply due to differences in precipitation rates and therefore incorporation dynamics of elemental impurities (Strasser et al. 2008, Walther et al. 2010). In addition, other studies have quantified the elemental composition of the endolymph fluid from which the otolith is mineralized and found heterogeneity between dissolved elements and proteins in the proximal and distal regions of the endolymph (Payan et al. 1999, $2004 \mathrm{~b})$. The endolymph fluid in trout was found to contain $20 \%$ higher $\mathrm{Na}^{+}$concentration on the proximal side, which is the same side on which the sulcus is formed (Payan et al. 1999). Consistent with our results, Sr:Ca ratios displayed a uniform distribution along the proximo-distal axis in turbot otoliths that was related to homogeneous dissolved $\mathrm{Sr}^{2+}$ concentration in the endolymph (Payan et al. 1999).

\section{CONCLUSIONS}

This is the first controlled laboratory study to examine the effects of hypoxic stress on otolith chemistry and one of the few studies to investigate the influence of sex on otolith elements. Constant hypoxia exposure over 4 or 10 wk did not affect element incorporation in the otoliths of Atlantic croaker. Periodic hypoxia did influence element incorporation in complex and interactive ways, and the exact mechanism of the hypoxic stress and sex influence is unclear. Otolith $\mathrm{Mn}: \mathrm{Ca}$ was the only element ratio not affected by endogenous hypoxic stress, and thus may serve as a promising environmental indicator of hypoxic redox conditions.

Acknowledgements. We thank S. Lawson at the University of Texas Marine Science Institute for fish care and maintenance of the DO conditions in the experimental tanks; and N. Miller at the Jackson School of Geosciences, University of Texas at Austin, for help with otolith analysis. This study was supported by NOAA Coastal Ocean Program Gulf of Mexico (grant no. NA09NOS4780179) to P.T. and the EPA STAR Fellowship to J.M.

\section{LITERATURE CITED}

Bath G, Thorrold SR, Jones CM, Campana SE, McLaren J, Lam JWH (2000) Strontium and barium uptake in aragonitic otoliths of marine fish. Geochim Cosmochim Acta 64:1705-1714

Bath Martin G, Thorrold SR (2005) Temperature and salinity effects on magnesium, manganese, and barium incorporation in otoliths of larval and early juvenile spot Leiosto- mus xanthurus. Mar Ecol Prog Ser 293:223-232

Bath Martin G, Wuenschel MJ (2006) Effect of temperature and salinity on otolith element incorporation in juvenile gray snapper Lutjanus griseus. Mar Ecol Prog Ser 324: 229-239

Bickler PE, Buck LT (2007) Hypoxia tolerance in reptiles, amphibians, and fishes: life with variable oxygen availability. Annu Rev Physiol 69:145-170

> Campana SE (1983) Calcium deposition and otolith check formation during periods of stress in coho salmon, Oncorhynchus kisutch. Comp Biochem Physiol A Physiol 75: 215-220

> Campana SE (1999) Chemistry and composition of fish otoliths: pathways, mechanisms and applications. Mar Ecol Prog Ser 188:263-297

> Craig JK (2012) Aggregation on the edge: effects of hypoxia avoidance on the spatial distribution of brown shrimp and demersal fishes in the Northern Gulf of Mexico. Mar Ecol Prog Ser 445:75-95

> Craig JK, Crowder LB (2005) Hypoxia-induced habitat shifts and energetic consequences in Atlantic croaker and brown shrimp on the Gulf of Mexico shelf. Mar Ecol Prog Ser 294:79-94

Creekmore SB (2011) Modeling the population effects of hypoxia on Atlantic croaker (Micropogonias undulatus) in the northwestern Gulf of Mexico. MSc thesis, Louisiana State University, Baton Rouge, LA

Diaz RJ, Rosenberg R (2008) Spreading dead zones and consequences for marine ecosystems. Science 321:926-929

> Dorval E, Jones CM, Hannigan R, Van Montfrans J (2007) Relating otolith chemistry to surface water chemistry in a coastal plain estuary. Can J Fish Aquat Sci 64:411-424

Elsdon TS, Gillanders BM (2002) Interactive effects of temperature and salinity on otolith chemistry: challenges for determining environmental histories of fish. Can J Fish Aquat Sci 59:1796-1808

Elsdon TS, Gillanders BM (2003) Relationship between water and otolith elemental concentrations in juvenile black bream Acanthopagrus butcheri. Mar Ecol Prog Ser 260:263-272

> Elsdon TS, Gillanders BM (2004) Fish otolith chemistry influenced by exposure to multiple environmental variables. J Exp Mar Biol Ecol 313:269-284

Elsdon TS, Gillanders BM (2005) Alternative life-history patterns of estuarine fish: barium in otoliths elucidates freshwater residency. Can J Fish Aquat Sci 62: 1143-1152

Forrester GE (2005) A field experiment testing for correspondence between trace elements in otoliths and the environment and for evidence of adaptation to prior habitats. Estuaries 28:974-981

> Froeschke JT, Stunz GW (2011) Hierarchical and interactive habitat selection in response to abiotic and biotic factors: the effect of hypoxia on habitat selection of juvenile estuarine fishes. Environ Biol Fishes 93:31-41

> Gaetani GA, Cohen AL (2006) Element partitioning during precipitation of aragonite from seawater: a framework for understanding paleoproxies. Geochim Cosmochim Acta 70:4617-4634

> Hochachka PW, Buck LT, Doll CJ, Land SC (1996) Unifying theory of hypoxia tolerance: molecular/metabolic defense and rescue mechanisms for surviving oxygen lack. Proc Natl Acad Sci USA 93:9493-9498

Kalish JM (1991) Determinants of otolith chemistry: seasonal variation in the composition of blood plasma, endolymph and otoliths of bearded rock cod Pseudophycis barbatus. Mar Ecol Prog Ser 74:137-159 
Kalish JM (1992) Formation of a stress-induced chemical check in fish otoliths. J Exp Mar Biol Ecol 162:265-277

Kodama K, Rahman MS, Horiguchi T, Thomas P (2012) Assessment of hypoxia-inducible factor-1 $\alpha$ mRNA expression in mantis shrimp as a biomarker of environmental hypoxia exposure. Biol Lett 8:278-281

Limburg KE, Olson C, Walther Y, Dale D, Slomp CP, Høie H (2011) Tracking Baltic hypoxia and cod migration over millennia with natural tags. Proc Natl Acad Sci USA 108: E177-E182

Maillet GL, Checkley DM (1990) Effects of starvation on the frequency of formation and width of growth increments in sagittae of laboratory-reared Atlantic menhaden Brevoortia tyrannus larvae. Fish Bull 88:155-165

McNatt RA, Rice JA (2004) Hypoxia-induced growth rate reduction in two juvenile estuary-dependent fishes. J Exp Mar Biol Ecol 311:147-156

$>$ Miller JA (2009) The effects of temperature and water concentration on the otolith incorporation of barium and manganese in black rockfish Sebastes melanops. J Fish Biol 75:39-60

Miller JA (2011) Effects of water temperature and barium concentration on otolith composition along a salinity gradient: implications for migratory reconstructions. J Exp Mar Biol Ecol 405:42-52

Miller MB, Clough AM, Batson JN, Vachet RW (2006) Transition metal binding to cod otolith proteins. J Exp Mar Biol Ecol 329:135-143

Mohan JA, Rulifson RA, Corbett DR, Halden NM (2012) Validation of oligohaline elemental otolith signatures of striped bass by use of in situ caging experiments and water chemistry. Mar Coast Fish 4:57-70

- Nikinmaa M, Rees BB (2005) Oxygen-dependent gene expression in fishes. Am J Physiol Regul Integr Comp Physiol 288:R1079-R1090

Pakhomova SV, Hall POJ, Kononets MY, Rozanov AG, Tengberg A, Vershinin AV (2007) Fluxes of iron and manganese across the sediment-water interface under various redox conditions. Mar Chem 107:319-331

Paton C, Hellstrom J, Paul B, Woodhead J, Hergt J (2011) Iolite: freeware for the visualization and processing of mass spectrometric data. J Anal At Spectrom 26: 2508-2518

Payan P, Edeyer A, De Pontual H, Borelli G, Boeuf G, MayerGostan N (1999) Chemical composition of saccular endolymph and otolith in fish inner ear: lack of spatial uniformity. Am J Physiol 277:R123-R131

Payan P, De Pontual H, Bœuf G, Mayer-Gostan N (2004b) Endolymph chemistry and otolith growth in fish. C R Palevol 3:535-547

Payan P, De Pontual H, Edeyer A, Borelli G, Boeuf G, MayerGostan N (2004a) Effects of stress on plasma homeostasis, endolymph chemistry, and check formation during otolith growth in rainbow trout (Oncorhynchus mykiss). Can J Fish Aquat Sci 61:1247-1255

Radtke RL (1989) Strontium-calcium concentration ratios in fish otoliths as environmental indicators. Comp Biochem Physiol A Comp Physiol 92:189-193

> Rahman MS, Thomas P (2007) Molecular cloning, characterization and expression of two hypoxia-inducible factor alpha subunits, HIF- $1 \alpha$ and HIF- $2 \alpha$, in a hypoxia-tolerant marine teleost, Atlantic croaker (Micropogonias undulatus). Gene 396:273-282

Rahman MS, Thomas P (2012) Effects of hypoxia exposure on hepatic cytochrome P450 1A (CYP1A) expression in Atlantic croaker: molecular mechanisms of CYP1A down-regulation. PLoS ONE 7:e40825

Sadovy Y, Severin KP (1992) Trace elements in biogenic aragonite: correlation of body growth rate and strontium levels in the otoliths of the white grunt, Haemulon plumieri (Pisces: Haemulidae). Bull Mar Sci 50:237-257

> Sinclair D (2005) Correlated trace element 'vital effects' in tropical corals: a new geochemical tool for probing biomineralization. Geochim Cosmochim Acta 69:3265-3284

> Slomp CP, Malchaert JFP, Lohse L, Van Raaphorst W (1997) Iron and manganese cycling in different sedimentary environments on the North Sea continental margin. Cont Shelf Res 17:1083-1117

> Slowey JF, Hood DW (1971) Copper, manganese and zinc concentrations in Gulf of Mexico waters. Geochim Cosmochim Acta 35:121-138

> Statham PJ, Connelly DP, German CR, Brand T and others (2005) Spatially complex distribution of dissolved manganese in a fjord as revealed by high-resolution in situ sensing using the autonomous underwater vehicle Autosub. Environ Sci Technol 39:9440-9445

Strasser CA, Mullineaux LS, Walther BD (2008) Growth rate and age effects on Mya arenaria shell chemistry: implications for biogeochemical studies. J Exp Mar Biol Ecol 355:153-163

> Sturrock AM, Trueman CN, Darnaude AM, Hunter E (2012) Can otolith elemental chemistry retrospectively track migrations in fully marine fishes? J Fish Biol 81:766-795

Thamdrup B, Glud RN, Hansen JW (1994) Manganese oxidation and in situ manganese fluxes from a coastal sediment. Geochim Cosmochim Acta 58:2563-2570

> Thomas P, Rahman MS (2009) Biomarkers of hypoxia exposure and reproductive function in Atlantic croaker: A review with some preliminary findings from the northern Gulf of Mexico hypoxic zone. J Exp Mar Biol Ecol 381: S38-S50

Thomas P, Rahman S (2012) Extensive reproductive disruption, ovarian masculinization and aromatase suppression in Atlantic croaker in the northern Gulf of Mexico hypoxic zone. Proc R Soc Lond B Biol Sci 279:28-38

> Thorrold SR, Shuttleworth S (2000) In situ analysis of trace elements and isotope ratios in fish otoliths using laser ablation sector field inductively coupled plasma mass spectrometry. Can J Fish Aquat Sci 57:1232-1242

Thorrold SR, Jones CM, Campana SE (1997) Response of otolith microchemistry to environmental variations experienced by larval and juvenile Atlantic croaker (Micropogonias undulatus). Limnol Oceanogr 42:102-111

Walther BD, Limburg KE (2012) The use of otolith chemistry to characterize diadromous migrations. J Fish Biol 81: 796-825

Walther BD, Thorrold SR (2006) Water, not food, contributes the majority of strontium and barium deposited in the otoliths of a marine fish. Mar Ecol Prog Ser 311:125-130

> Walther BD, Thorrold SR (2008) Continental-scale variation in otolith geochemistry of juvenile American shad (Alosa sapidissima). Can J Fish Aquat Sci 65:2623-2635

Walther BD, Kingsford MJ, O'Callaghan MD, McCulloch MT (2010) Interactive effects of ontogeny, food ration and temperature on elemental incorporation in otoliths of a coral reef fish. Environ Biol Fishes 89:441-451

- Woodcock SH, Munro AR, Crook DA, Gillanders BM (2012) Incorporation of magnesium into fish otoliths: determining contribution from water and diet. Geochim Cosmochim Acta 94:12-21

- Wu RSS (2002) Hypoxia: from molecular responses to ecosystem responses. Mar Pollut Bull 45:35-45

Submitted: August 2, 2013; Accepted: October 24, 2013

Proofs received from author(s): November 22, 2013 